\title{
Blueberry Shoestring Virus in Eastern North American Populations of Native Vaccinium
}

\author{
J.F. Hancock ${ }^{1}$, P.W. Callow ${ }^{1}$, S.L. Krebs ${ }^{1}$, and D.C. Ramsdell ${ }^{2}$ \\ Michigan State University, East Lansing, MI 48824
}

J.R. Ballington

Department of Horticultural Science, North Carolina State University, Raleigh, NC 27695

\author{
M.J. Lareau \\ Agriculture Canada Research Station, 430 Govin, St-Jean-Sur-Richelieu, \\ Qué. J3B 628, Canada
}

\section{J.J. Luby \\ Department of Horticultural Science, University of Minnesota, St. Paul, MN 55108}

\author{
G.P. Pavlis \\ Atlantic County Extension Office, Mays Landing, NJ 08330
}

\author{
M.P. Pritts \\ Department of Fruit and Vegetable Science, Cornell University,, Ithaca, \\ NY 14853
}

\section{J.M. Smagula}

Department of Plant and Soil Science, University of Maine, Orono, ME 04469

\author{
N. Vorsa \\ Cranberry and Blueberry Research Center, Rutgers University, Chatsworth, \\ NJ 08019
}

Additional index words. BBSSV, blueberry breeding, Illinoia pepperi

\begin{abstract}
Flower bud and leaf samples collected from a wide range of native North American Vaccinium populations were tested for the presence of blueberry shoestring virus (BBSSV) using the enzyme-linked immunosorbant assay. The highest disease incidence was found in Michigan (14\%), although a few positive samples also were found in Virginia, New Jersey, Maine, Ontario, and Quebec. Of seven species tested, only $V$. corymbosum $L$. and $V$. angustifolium Ait. were infected with BBSSV.
\end{abstract}

Blueberry shoestring virus (BBSSV) causes shoestring disease, the most important viral disease of blueberry in Michigan. It also has been reported in North Carolina, New Jersey, Washington, New Brunswick, and Nova Scotia, although it has not reached epidemic proportions in these areas (Lockhart and Hall, 1962; Ramsdell, 1979). The most common shoestring disease symptoms are reddish streaking on young stems, strap-shapedleaves, and reduced vigor (Ramsdell, 1979). BBSSV is vectored by the aphid Illinoia pepperi (Mac

Received for publication 29 June 1992. Accepted for publication 23 Oct. 1992. The cost ofpublishing this paper was defrayed in part by the payment of page charges. Under postal regulations, this paper therefore must be hereby marked advertisement solely to indicate this fact.

${ }^{1}$ Dept. of Horticulture.

${ }^{2}$ Dept. of Botany and Plant Pathology.
G) (Morimoto and Ramsdell, 1985; Morimoto et al., 1985).

Several characteristics make BBSSV particularly difficult to eradicate. Infected bushes do not show symptoms for as many as 4 years. As a result, disease spread can be unnoticed for several years and the virus carried accidentally in propagated stock. In addition, no Vaccinium corymbosum cultivar is immune to the disease (Hancock et al., 1986) or its aphid vector (Hancock et al., 1982).

Another characteristic is that the disease can spread from natural blueberry populations to commercial fields. Illinoia pepperi is found on native and feral blueberry plants that often are close to cultivated fields (Kriegle, 1985). In a previous study, we found a high incidence of the disease in native Michigan $V$. corymbosum and $V$. angustifolium populations, even though they showed no symptoms. We report on disease prevalence across a broader spectrum of North American areas.
Flower bud and leaf samples were collected from a wide range of native Vaccinium populations in most of eastern North America (Table 1). One to three plants were collected per site, except in Michigan, Manitoba, New Jersey, and Maine, where five to seven clones were sampled per site. None of the donor plants showed shoestring disease symptoms. Most of the samples came directly from the wild. In several instances, however, wild plants had been collected and held in a greenhouse or field for several years before being sampled. Aphicides were sprayed regularly on captive plants. Flower bud samples were taken at first swell; leaf samples were taken at the rosette stage, soon after spring emergence. Tissues in these stages previously carried the highest virus titer of the growing season, although distribution among shoots may have been irregular (Schulte et al., 1985).

Five-gram leaf samples or 25 flower buds were tested for the presence of BBSSV using the double-antibody sandwich enzyme-linked immunosorbant assay (ELISA) (Schulte et al., 1985). Plant tissue samples were diluted 1:10 (w/v) with a phosphate-buffered saline solution, $\mathrm{pH} 7.4$, containing $2.0 \%$ polyvinyl pyrrolidone (MW40,000) (v/v), 0.2\% ovalbu$\min (\mathrm{w} / \mathrm{v})$, and $0.05 \%$ Tween-20 (v/v). The plant material was then triturated with a Tissumizer homogenizer (Tekmar Co., Cincinnati). The samples were kept at 0 to $5 \mathrm{C}$ for 2 to 4 days until they were analyzed. BBSSV was purified from frozen infected $V$. corymbosum 'Jersey' blossoms as described by Schulte et al. (1985). Antiserum was produced by injecting a New Zealand white rabbit intramuscularly with BBSSV once a week for 3 weeks. Flat-bottom polystyrene microtiter plates (Dynatech Laboratories, Alexandria, Va.) were coated with $1 \mu \mathrm{g}$ of anti-BBSSV- $\gamma$ globulin $/ \mathrm{ml}$ in coating buffer $(0.05 \mathrm{M}$ sodium carbonate-bicarbonate buffer, $\mathrm{pH}$ 9.6) at a volume of $200 \mu \mathrm{l} /$ well and incubated for $3 \mathrm{~h}$ at 37C. Blueberry plant samples were added in $200-\mu l$ aliquots to replicate wells. Two-hundred microliters of a 1:800 dilution (in extraction buffer) of enzyme-labeled BBSSV $\alpha-$ globulin (conjugate) was added to each well and incubated for $4 \mathrm{~h}$ at $37 \mathrm{C}$. Samples were considered positive if their absorbancy was higher than the mean $A_{405 \mathrm{~mm}}$ value of three healthy blueberry control wells plus 2 SD units.

The highest disease incidence was found in Michigan, where $14 \%$ of the samples was ELISA positive (Table 1). This compares to $20 \%$ found in the previous study (Hancock et al., 1986). Positive samples also were found in Virginia, New Jersey, Maine, Ontario, and Quebec, but only one diseased plant was found in each area. In Michigan, three $V$. angustifolium populations and one $V$. corymbosum population had two diseased individuals, while the other populations had only one.

Of the seven Vaccinium species tested in this study, only tetraploid $V$. corymbosum and $V$. angustifolium were infected (Table 1). These are the most widely distributed species in Michigan, where disease incidence was highest. Only a few individuals of $V$. myrtilloides 
Table 1. Number of blueberry (Vaccinium spp.) clones infected with blueberry shoestring virus in native North American populations.

\begin{tabular}{|c|c|c|c|c|}
\hline Location & Species $^{y}$ & $\begin{array}{c}\text { Locations }^{z} \\
\text { (no.) }\end{array}$ & $\begin{array}{c}\text { Total } \\
\text { clones } \\
\text { (no.) }\end{array}$ & $\begin{array}{c}\text { Diseased } \\
\text { clones } \\
\text { (no.) }\end{array}$ \\
\hline \multicolumn{5}{|l|}{ Midwestern } \\
\hline Manitoba & V. angustifolium & 4 & 28 & 0 \\
\hline \multirow[t]{2}{*}{ Michigan } & V. angustifolium & 15 & 70 & 10 \\
\hline & V. corymbosum, $4 \mathrm{x}$ & 7 & 38 & 5 \\
\hline Minnesota & $V$. angustifolium & 8 & 22 & 0 \\
\hline \multirow[t]{2}{*}{ Wisconsin } & V. angustifolium & 6 & 10 & 0 \\
\hline & $V$ corymbosum, $4 \mathrm{x}$ & 1 & 1 & 0 \\
\hline Total & & 41 & 169 & 15 \\
\hline \multicolumn{5}{|l|}{ Mid-Atlantic } \\
\hline New Jersey & V. corymbosum, $4 \mathrm{x}$ & 5 & 30 & 1 \\
\hline \multirow[t]{4}{*}{ New York } & V. angustifolium & 3 & 4 & 0 \\
\hline & V. corymbosum, $4 \mathrm{x}$ & 4 & 4 & 0 \\
\hline & $V$. pallidum & 5 & 6 & 0 \\
\hline & V. myrtilloides & 1 & 1 & 0 \\
\hline \multirow[t]{2}{*}{ Virginia } & V. corymbosum, $2 \mathrm{x}$ & 1 & 1 & 0 \\
\hline & V. corymbosum, $4 \mathrm{x}$ & 3 & 13 & 1 \\
\hline Total & & 22 & 59 & 2 \\
\hline \multicolumn{5}{|l|}{ Northeast } \\
\hline Maine & V. angustifolium & 24 & 120 & 1 \\
\hline Massachusetts & V. corymbosum, $4 \mathrm{x}$ & 1 & 1 & 0 \\
\hline Ontario & V. angustifolium & 3 & 15 & 1 \\
\hline Quebec & V. corymbosum, $4 \mathrm{x}$ & 43 & 44 & 1 \\
\hline Total & & 71 & 180 & 3 \\
\hline \multicolumn{5}{|l|}{ South } \\
\hline \multirow[t]{2}{*}{ Arkansas } & V. corymbosum, $4 \mathrm{x}$ & 2 & 3 & 0 \\
\hline & V.pallidum & 2 & 3 & 0 \\
\hline \multirow[t]{3}{*}{ Florida } & V. corymbosum, $2 \mathrm{x}$ & 2 & 2 & 0 \\
\hline & $V$. darrowi & 6 & 8 & 0 \\
\hline & V. myrsinites & 1 & 1 & 0 \\
\hline \multirow{5}{*}{ Georgia } & V. corymbosum, $2 \mathrm{x}$ & 2 & 4 & 0 \\
\hline & V. corymbosum, $4 \mathrm{x}$ & 4 & 6 & 0 \\
\hline & V. corymbosum, $6 \mathrm{x}$ & 3 & 4 & 0 \\
\hline & $V$. myrsinites & 1 & 1 & 0 \\
\hline & V. tenellum & 1 & 1 & 0 \\
\hline \multirow[t]{5}{*}{ North Carolina } & V. corymbosum, $2 \mathrm{x}$ & 14 & 18 & $\mathbf{0}$ \\
\hline & V. corymbosum, $2 \mathrm{x}-4 \mathrm{x}$ & 21 & 25 & 0 \\
\hline & V. corymbosum, $2 \mathrm{x}-6 \mathrm{x}$ & 4 & 10 & 0 \\
\hline & $V \cdot$ pallidum & 7 & 14 & 0 \\
\hline & V. tenellum & 5 & 6 & 0 \\
\hline \multirow{5}{*}{ South Carolina } & V. corymbosum, $2 \mathrm{x}$ & 5 & 6 & 0 \\
\hline & V. corymbosum, $4 \mathrm{x}$ & 4 & 4 & 0 \\
\hline & V. corymbosum, $6 \mathrm{x}$ & 3 & 4 & 0 \\
\hline & V. myrsinites & 1 & 1 & 0 \\
\hline & $V$. tenellum & 2 & 2 & 0 \\
\hline Total & & 90 & $12 \overline{3}$ & 0 \\
\hline
\end{tabular}

Each sample site within a state or province was separated from others by at least $10 \mathrm{~km}$.

'Species are listed according to Vander Kloet (1988). Camp's (1942) V. atrococcum and V. elliotti are contained within $V$. corymbosum, 2x; $V$. australe is within $V$. corymbosum, 4x; and $V$. ashei is within $V$. corymbosum, $6 \mathrm{x}$.

Michx., V. darrowi Camp, V. myrsinites Lamarck, V. pallidum Ait., and $V$. tenellum Ait. were evaluated, so we do not know whether they were immune to the disease or not exposed to it.

There are several possibilities as to why BBSSV is more prevalent in native Michigan blueberry populations than elsewhere. Its spread south probably is limited because the vector, I. pepperi, is not found in warm regions. However, the blueberry aphid is common in other northeastern, mid-Atlantic, and midwestem areas (Kriegle, 1985) that have a much lower disease incidence than Michigan.
The disease may have originated recently in native Michigan populations and only now is beginning to spread. Possibly, a more virulent strain of the virus exists in Michigan, or strains are vectored more efficiently by I. pepperi in Michigan than elsewhere. Further investigation is necessary to examine these possibilities.

Interestingly, BBSSV eventually debilitates Michigan cultivars, while infected native populations always are symptomless. Our most widely planted commercial types were developed from wild selections from the eastern United States (Hancock and Siefker, 1982), and native $V$. corymbosum in Michigan may be more tolerant to the disease. Unfortunately, little is known about BBSSV's origin and evolution.

\section{Literature Cited}

Camp, W.H. 1942. A survey of the American species of Vaccinium, subgenus Euvaccinium. Brittonia 4:205-247.

Hancock, J.F., K.M. Morimoto, N.L. Schulte, J.M. Martin, and D.C. Ramsdell. 1986. Search for resistance to blueberry shoestring virus in highbush blueberry, cultivars. Fruit Var. J. 40:5658:

Hancock, J.F., N.L. Schulte, J.H. Siefker, M.P. Pritts, and J.M. Roueche. 1982. Screening highbush blueberries for resistance to the aphid Illinois pepperi. HortScience 17:362-363.

Hancock, J.F. and J.H. Sietker. 1982. Levels of inbreeding in highbush blueberry cultivars. HortScience 18:363-366.

Kriegle, R.D. 1985. The population dynamics and dispersal of the blueberry aphid, Illinoia pepperi (Mac G.). MS Thesis, Michigan State Univ., East Lansing.

Lockhart, C.L. and I.V. Hall. 1962. Note on an indication of shoestring virus in the lowbush blueberry Vaccinium angustifolium Ait. Can. J. Bot. 40:1561-1562.

Morimoto, K.M. and DC. Ramsdell. 1985. Aphid vector population dynamics and movement relative to field transmission of blueberry shoestring virus. Phytopathology 75:1217-1222.

Morimoto, K.M., D.C. Ramsdell, J.M. Gillett, and W.G. Chaney. 1985. Acquisition and transmission of blueberry shoestring virus by its aphid vector Illinoia pepperi. Phytopathology 75:709712.

Ramsdell, D.C. 1979. Blueberry shoestring virus, no. 204. CMI/AAR descriptions of plant viruses. Kew, Surrey, England.

Schulte, N.L., J.F. Hancock, and D.C. Ramsdell. 1985. Development of a screen for resistance to blueberry shoestring virus. J. Amer. Soc. Hort. Sci. 110:343-346.

Vander Kloet, S.P. 1988. The genus Vaccinium in North America. Publ. 1828. Res. Branch Agr. Can., Ottawa. 